\title{
KAJIAN INTERAKSI OBAT ANTIHIPERTENSI PADA PASIEN HEMODIALISIS DI BANGSAL RAWAT INAP RSU PKU MUHAMMADIYAH YOGYAKARTA PERIODE TAHUN 2010
}

\section{THE ANTIHYPERTENSIVE DRUG INTERACTION STUDIES FOR HEMODIALYSIS PATIENTS IN THE INPATIENT OF PKU MUHAMMADIYAH YOGYAKARTA HOSPITAL ON 2010 PERIOD}

\author{
Siti Rahmiati, Woro Supadmi \\ Fakultas Farmasi Universitas Ahmad Dahlan \\ Email :wsupatmi@yahoo.com
}

\section{Abstrak}

Interaksi obat merupakan salah satu Drug Related Problems (DRPs) yang dapat mempengaruhi luaran terapi pasien. Hipertensi terjadi pada sekitar 10\% sampai 81,5\% pasien hemodialisis. Tujuan penelitian ini adalah untuk mengetahui kejadian interaksi obat antihipertensi pada pasien hemodialisis di bangsal rawat inap RSU PKU Muhammadiyah Yogyakarta periode tahun 2010. Penelitian ini merupakan penelitian dengan rancangan deskriptif. Data diambil secara retrospektif. Pengambilan data dilakukan dengan cara mengambil semua data yang memenuhi kriteria penelitian yang ada pada rekam medik pasien hemodialisis di RSU PKU Muhammadiyah Yogyakarta. Pasien mendapat antihipertensi dengan tekanan darah diatas normal atau $=130 / 80$ mmHg. Data dianalisis secara deskriptif berdasarkan tingkat signifikansi, onset, dan severity. Hasil penelitian menunjukkan bahwa terdapat 54,79\% (40 pasien) dari 73 pasien hemodialisis berpotensi mengalami interaksi obat. Obat antihipertensi yang paling banyak digunakan pada pasien hemodialisis adalah ACEI, CCB, dan diuretik. Kejadian interaksi obat antihipertensi yang paling banyak terjadi adalah pada tingkat signifikansi 3 terdapat 27 kasus (45,76\%), Onset yaitu delayed sebesar 48 kasus (81,36\%), dan severity yaitu minor sebesar 44 kasus (74,58\%). Mekanisme interaksi terbanyak yaitu farmakodinamik 37 kasus (62,71\%) dari total 59 kejadian yang mengalami interaksi obat. Jenis obat yang sering berinteraksi adalah furosemid dan kaptopril.

Kata kunci : Interaksi obat, antihipertensi, hemodialisis 


\section{Abstract}

Drug interactions are one of the Drug Related Problems (DRPs) that may affect patient treatment outcomes. Hypertension occurs in approximately $10 \%$ to $81.5 \%$ of hemodialysis patients. The purpose of this study was to determine the incidence of antihypertensive drug interactions in hemodialysis patients in the inpatient wards PKU Muhammadiyah Hospital of Yogyakarta period in 2010. This study descriptive design. Data retrieved retrospectively. Data retrieval were done by taking all the data that meet the criteria of existing research on the medical records of hemodialysis patients in PKU Muhammadiyah Hospital of Yogyakarta who received antihypertensive with above normal blood pressure (=130/80 $\mathrm{mmHg})$. Data were analyzed based on the descriptive level of significance, onset, and severity. The results showed that there were $54.79 \%$ (40 patients) of 73 hemodialysis patients potentially experienced drug interactions. Antihypertensive drugs most widely used in hemodialysis patients were $A C E I, C C B$, and diuretics. Incidence of antihypertensive drug interactions 27 cases (45.76\% were most common at a significance level 3, 48 cases (81.36\%) were onset delayed, and the severity minor of 44 cases (74.58\%). The mechanism of interactions pharmacodynamic were 37 cases (62.71\%) of the total 59 events that have drug interactions. Drugs often interactions were furosemide and captopril.

Key words : drug interactions, antihypertensive, hemodialysis

\section{PENDAHULUAN}

Hemodialisis merupakan suatu terapi pengganti ginjal yang dilakukan apabila ginjal pasien sudah tak bisa berfungsi optimal untuk mempertahankan cairan, elektrolit, dan membuang sisa-sisa metabolisme dari tubuhnya. Menurut data yang dikumpulkan the National Health and Nutrition Examination Survey, terdapat sekitar $11,5 \%$ dari keseluruhan penduduk yang berusia 20 tahun keatas di Amerika Serikat yang membutuhkan terapi ini. Ironisnya, hanya sebagian kecil dari nilai estimasi tersebut yang benar-benar menjalani terapi hemodialisis dikarenakan berbagai alasan. Pada tahun 2006, pemerintah Amerika mengestimasi sekitar \$33.61 miliar yang telah dikeluarkan untuk menjalankan program ini (NKUDIC, 2009).

Pada dekade terakhir, dialisis sebagai terapi pengganti fungsi ginjal mendapat sambutan hangat di berbagai negara karena dapat meningkatkan harapan hidup pasien. Lebih dari 350.000 pasien di Amerika Serikat menjalani hemodialisis. Jumlah pasien yang harus menjalani hemodialisis meningkat secara bertahap kenaikan jumlah pasien yang paling banyak adalah pasien diatas 65 tahun. Di Indonesia hemodialisis dimulai pada tahun 1970 dan sampai sekarang telah dilaksanakan di banyak rumah sakit rujukan. Kualitas hidup cukup baik dan panjang umur yang 
tertinggi sampai sekarang 14 tahun. Kendala yang ada adalah biaya yang mahal (Rahardjo dkk., 2001).

Hemodialisis menyebabkan terjadinya hipertensi intradialitik karena aktivasi berbagai vasopresor endogen akibat adanya perubahan status volume maupun faktor terdialisisnya obat antihipertensi. Studi terbaru menyebutkan bahwa yang berperan penting dalam hemodialisis adalah kelebihan volume cairan, perubahan hemodinamik, tingkat endothelin, aktivasi sistem reninangiotensin, dan aktivitas berlebihan pada saraf simpatis. Hipertensi intradialitik terjadi pada sekitar $10 \%$ pasien hemodialisis dan mempengaruhi hingga $15 \%$ dari pasien hemodialisis (Chazot dan Guillaume, 2010; Inrig, 2010).

Hasil survey di United State menyebutkan bahwa 2535 pasien hemodialisis dari 69 unit dialisis, prevalensi kejadian hipertensi sebanyak 86\% (Agarwal, 2006). Penelitian oleh Melati dan Benyamin pada tahun 2008 menyebutkan bahwa $81,5 \%$ penderita dengan inisiasi hemodialisis mengalami hipertensi. Sekresi renin yang berlebihan, mengakibatkan peningkatan kadar natrium dan volume cairan sehingga terjadi hipertensi (Weidman et al, 1971).

Pasien dialisis mempunyai patofisiologi yang komplek, dengan beberapa penyakit penyulit 5 sampai 6 , membutuhkan regimen terapi yang komplek. Hal ini meningkatkan resiko timbulnya Drug Related Problems $(D R P s)$. Interaksi obat merupakan salah satu $D R P S$ yang dapat mempengaruhi luaran terapi pasien. Interaksi obat dapat terjadi tetapi interaksi obat tidak selalu berakibat merugikan secara klinis, namun banyak juga interaksi yang mempunyai efek potensial yang merugikan pada sebagian pasien (Anonim, 2000). Penelitian oleh Grabe, et al (1997), pada pasien rawat jalan yang menjalani hemodialisis, dari 45 pasien didapatkan $D R P s$ yang terbanyak adalah interaksi obat $(27,5 \%)$. Dua kelompok obat yang dikatakan potensial menjadi objek dalam interaksi obat yaitu: obatobat yang mempunyai indeks terapi sempit (misalnya fenitoin) dan obat-obat yang memerlukan kontrol dosis yang tepat adalah antikoagulan, antihipertensi, antidiabetik (Anonim, 2000).

Beberapa studi memperkirakan kejadian interaksi obat berkisar antara 2,2 $\%$ sampai $30 \%$ pada pasien yang ada di rumah sakit dan 9,2\% sampai 70,3\% pada pasien luar rumah sakit. Berdasarkan data tersebut disimpulkan bahwa obat-obat yang potensial menimbulkan interaksi sulit untuk diketahui ketika pasien menunjukkan gejala-gejala akibat interaksi obat, tetapi interaksi yang secara klinik dikatakan signifikan adalah kurang lebih hanya $1 \%$ (Walker dan Edwards, 1999).

Rumah Sakit Umum PKU Muhammadiyah merupakan rumah sakit swasta daerah kota Yogyakarta serta rumah sakit rujukan untuk penyakit gagal ginjal. Di rumah sakit ini, tersedia unit hemodialisis sehingga jumlah kasus gagal ginjal kronik cukup banyak termasuk 10 besar penyakit dengan kasus terbanyak di rumah sakit umum PKU Muhammadiyah Yogyakarta. 


\section{METODE PENELITIAN}

\section{Rancangan penelitian}

Penelitian ini bersifat deskriptif, dengan mengumpulkan data secara retrospektif. Sumber data pada penelitian ini adalah data pengobatan pada rekam medis pasien hemodialisis yang mendapat obat antihipertensi di bangsal hemodialisis Rumah Sakit Umum PKU Muhammadiyah Yogyakarta pada periode 2010. Data yang diperoleh dianalisis dan disajikan secara diskriptif untuk mengetahui jumlah pasien, pola pengobatan antihipertensi, jumlah pasien hemodialisis yang mengalami kejadian interaksi obat antihipertensi, dan kajian interaksi obat antihipertensi berdasarkan onset, severity, dan signifikansi.

\section{Definisi operasional variabel}

1. Interaksi obat dianalisis berdasarkan buku Drug Interaction Facts $5^{\text {th }}$ Edition oleh David S. Tatro.

2. Pasien adalah semua pasien hemodialisis yang mendapat obat antihipertensi dan mengalami kenaikan tekanan darah diatas normal yaitu tekanan darah sistolik $=130 \mathrm{mmHg}$ atau tekanan darah diastolik $=80$ $\mathrm{mmHg}$ di bangsal rawat inap RSU PKU Muhammadiyah Yogyakarta pada periode 2010 .

3. Rekam medis adalah rekam medis pasien yang menjalani hemodialisis di rumah sakit umum PKU Muhammadiyah Yogyakarta pada periode 2010.

4. Kajian interaksi yang dibahas dalam penelitian ini yaitu interaksi obat antihipertensi dengan obat lain yang meliputi: jenis obat yang berinteraksi, signifikansi, onset, dan severity.

5. Signifikansi; penilaian terhadap tingkat keberbahayaan interaksi yang terjadi dari data dukomentasi klinik yang tercatat, terdiri dari tingkat signifikansi 1 sampai signifikansi 5 berdasarkan buku Drug Interaction Facts $5^{\text {th }}$ Edition oleh David S. Tatro.

6. Onset; seberapa cepat efek klinis dari suatu interaksi obat dapat terjadi dan menentukan tindakan yang harus dilakukan untuk menghindari akibat dari interaksi tersebut berdasarkan buku Drug Interaction Facts $5^{\text {th }}$ Edition oleh David S. Tatro.

7. Severity; potensi keberbahayaan interaksi obat dalam menilai resiko dibandingkan dengan keuntungan alternatif terapi yang terjadi berdasarkan buku Drug Interaction Facts $5^{\text {th }}$ Edition oleh David S. Tatro.

\section{Analisis data}

Data penelitian dianalisis berdasarkan acuan yang resmi, yaitu:

1. Buku Informatorium Obat Nasional Indonesia tahun 2008 untuk mengetahui informasi tentang obat secara umum, buku Drug Information Handbook volume 1 dan 2, digunakan untuk menganalisis khasiat obat-obat yang digunakan.

2. Kajian interaksi obat antihipertensi dengan obat lain dianalisis berdasarkan buku Drug Interaction Fact $5^{\text {th }}$ Edition oleh David S. Tatro serta Interaksi dianalisis berdasarkan tingkat signifikansi 1 sampai 5, onset, dan severity. 
3. Persentase jumlah pasien Muhammadiyah Yogyakarta, jenis hemodialisis yang mengalami kejadi- kelamin paling banyak mengalami gagal an interaksi obat antihipertensi, ginjal kronik dengan komplikasi mekanisme interaksi dan obat yang hipertensi adalah laki-laki. Kelompok sering berinteraksi berdasarkan hasil usia terbanyak mengalami gagal ginjal penelitian. kronik adalah pada kelompok usia 41-65 tahun.

Tabel I. Distribusi Pasien Hemodialisis yang Mendapat Antihipertensi di Bangsal Rawat Inap RSU PKU Muhammadiyah Yogyakarta Periode 2010

\begin{tabular}{|c|c|c|c|c|}
\hline No & \multicolumn{2}{|c|}{$\begin{array}{c}\text { KARAKTERISTIK } \\
\text { PASIEN }\end{array}$} & $\begin{array}{l}\text { JUMLAH } \\
\text { (ORANG) }\end{array}$ & $\begin{array}{c}\text { PERSENTASE } \\
(\%)\end{array}$ \\
\hline 1 & Jenis kelami & $\begin{array}{l}\text { Laki-laki } \\
\text { Perempuan }\end{array}$ & $\begin{array}{l}48 \\
25\end{array}$ & $\begin{array}{l}65,75 \\
34,25\end{array}$ \\
\hline \multicolumn{3}{|c|}{ TOTAL } & 73 & $100 \%$ \\
\hline 2 & Usia & $\begin{array}{c}<25 \text { tahun } \\
25-40 \text { tahun } \\
41-65 \text { tahun } \\
>65 \text { tahu }\end{array}$ & $\begin{array}{c}3 \\
15 \\
48 \\
7\end{array}$ & $\begin{array}{c}4,11 \\
20,55 \\
65,75 \\
9,59 \\
\end{array}$ \\
\hline \multicolumn{3}{|c|}{ TOTAL } & 73 & $100 \%$ \\
\hline
\end{tabular}

\section{HASIL DAN PEMBAHASAN}

\section{A. Karakteristik Pasien}

1. Distribusi pasien berdasarkan jenis kelamin dan umur

Pasien hemodialisis yang menjalani rawat inap di rumah sakit umum PKU Muhammadiyah Yogyakarta selama periode 2010 sebanyak 161. Pasien yang sesuai dengan kriteria dalam penelitian ini adalah pasien hemodialisis yang mendapat antihipertensi dengan tekanan darah diatas normal $(=130 / 80$ $\mathrm{mmHg}$ ) sebanyak 73 orang, dapat dilihat pada Tabel I.

Menurut hasil penelitian yang dilakukan di rumah sakit umum PKU
2. Klasifikasi tekanan darah pasien gagal ginjal dengan hemodialisis

Berdasarkan hasil penelitian, kebanyakan pasien gagal ginjal dengan hemodialisis mempunyai tekanan darah tinggi (tingkat II).

Pada Tabel II dapat dilihat bahwa pasien yang mengalami prehipertensi adalah sebanyak $5,48 \%$ (4 pasien), hipertensi tingkat I adalah 12,33\% (9 pasien), dan hipertensi tingkat II 82,19\% (60 pasien). Menurut National Kidney Foundation- KDOQI (2005) dan 7th Report of The Joint National Committee on Hypertension Evaluation and Treatment (2008), target tekanan darah pada pasien hipertensi dengan penyakit gagal ginjal sebagai faktor penyulit 
disarankan $<130 / 80 \mathrm{mmHg}$. Pencapaian tekanan darah dibawah $130 / 80 \mathrm{mmHg}$ sangat penting untuk mencegah progresivitas gagal ginjal kronik dan kerusakan ginjal lebih lanjut. hipertensi. National Kidney Foundation-KDOQI

merekomendasikan untuk hipertensi tingkat II (TD $>160 / 100 \mathrm{mmHg})$ menggunakan obat $A C E I$ atau $A R B$ dan

Tabel II. Klasifikasi Tekanan Darah Pasien

\begin{tabular}{|c|c|c|c|c|}
\hline $\begin{array}{c}\text { Klasifikasi } \\
\text { tekanan darah }\end{array}$ & $\begin{array}{l}\text { Sistolik } \\
(\mathbf{m m H g})\end{array}$ & $\begin{array}{l}\text { Diastolik } \\
\text { (mmHg) }\end{array}$ & Jumlah pasien & Persentase $(\%)$ \\
\hline Normal & $<120$ & $<80$ & 0 & 0 \\
\hline Prehipertensi & $120-139$ & $80-89$ & 4 & 5,48 \\
\hline Tingkat I & $140-159$ & $90-99$ & 9 & 12,33 \\
\hline Tingkat II & $\geq 160$ & $\geq 100$ & 60 & 82,19 \\
\hline \multicolumn{3}{|c|}{ TOTAL } & 73 & $100 \%$ \\
\hline
\end{tabular}

3. Pola pengobatan antihipertensi pada pasien hemodialisis

Berdasarkan hasil penelitian penggunaan obat antihipertensi pada pasien hemodialisis di bangsal rawat inap RSU PKU Muhammadiyah Yogyakarta dapat dilihat pada Tabel III.

Pada Tabel II dapat dilihat bahwa penggunaan obat tunggal pada pengobatan hipertensi untuk pasien hemodialisis adalah sebanyak 23,29\% (17 pasien), kombinasi 2 obat adalah 26,03\% (19 pasien), kombinasi 3 obat sebanyak $38,36 \%$ (28 pasien), dan kombinasi 4 obat atau lebih 12,33\% (9 pasien). Hasil penelitian menunjukkan bahwa sebagian besar pasien menggunakan kombinasi 3, obat antihipertensi yaitu ACEI (Angiotensio Converting Enzyme Inhibitor) CCB (Calcium Canal Bloker), dan diuretik untuk menurunkan tekanan darah pasien sampai $<130 / 80$ $\mathrm{mmHg}$. Penatalaksanaan hipertensi pada pasien dialisis terbagi dalam pengaturan status cairan dan penggunaan obat anti-
CCB, dan $7^{\text {th }}$ Report of The Joint National Committee on Hypertension Evaluation and Treatment (2008) menyarankan pasien hipertensi dengan penyakit gagal ginjal sebagai faktor penyulit menggunakan loop diuretik untuk mengurangi volume cairan. Pasien gagal ginjal dengan hemodialisis membutuh tiga agen atau lebih untuk mencapai target tekanan darah kurang dari $130 / 80 \mathrm{mmHg}$.

\section{B. Klasifikasi berdasarkan kejadian interaksi obat}

Pasien yang mengalami interaksi obat antihipertensi dengan obat lain yaitu terjadi interaksi sebesar 54,79\% (40 pasien) dan tidak terjadi interaksi sebesar $45,21 \%$ (33 pasien).

\section{Kajian Interaksi Obat}

\section{Kajian interaksi obat berdasarkan signifikansi 1}


Tabel III. Pola Pengobatan Anti- hipertensi pada Pasien Hemodialisis di Bangsal Rawat Inap RSU PKU Muhammadiyah Yogyakarta Periode 2010

\begin{tabular}{|c|c|c|c|c|c|}
\hline No. & Penggunaan & Nama obat & $\begin{array}{l}\text { Jumlah } \\
\text { pasien }\end{array}$ & $\begin{array}{l}\text { Total } \\
\text { jumlah } \\
\text { pasien }\end{array}$ & Persentase \\
\hline \multirow[t]{4}{*}{1} & \multirow[t]{4}{*}{ Obat tunggal } & Kaptopril & 4 & \multirow[t]{4}{*}{17} & \multirow[t]{4}{*}{23,29} \\
\hline & & Valsartan & 1 & & \\
\hline & & Furosemid & 11 & & \\
\hline & & Amlodipin & 1 & & \\
\hline \multirow[t]{10}{*}{2} & \multirow[t]{10}{*}{ Kombinasi 2 obat } & Kaptopril+ Furosemid & 3 & \multirow[t]{10}{*}{19} & \multirow[t]{10}{*}{26,03} \\
\hline & & Ramipril+Furosemid & 1 & & \\
\hline & & Lisinopril+Furosemid & 1 & & \\
\hline & & Valsartan+Furosemid & 4 & & \\
\hline & & Irbesartan+Furosemid & 1 & & \\
\hline & & Amlodipin+Furosemid & 2 & & \\
\hline & & Kaptopril+Nifedipin & 2 & & \\
\hline & & Kaptopril+Amlodipin & 3 & & \\
\hline & & Valsartan+Amlodipin & 1 & & \\
\hline & & Amlodipin + Klonidin & 1 & & \\
\hline \multirow[t]{10}{*}{3} & \multirow[t]{10}{*}{ Kombinasi 3 obat } & Ramipril+Furosemid+Nifedipin & 1 & \multirow[t]{10}{*}{28} & \multirow[t]{10}{*}{38,36} \\
\hline & & Kaptopril+Furosemid+Amlodipin & 2 & & \\
\hline & & Kaptoril+Furosemid+Nifedipin & 5 & & \\
\hline & & Telmisartan+Furosemid + Amlodipin & 2 & & \\
\hline & & Valsartan+Amlodipin+ Furosemid & 13 & & \\
\hline & & Amlodipin+Klonidin + Furosemid & 1 & & \\
\hline & & Nifedipin+Klonidin+Furosemid & 1 & & \\
\hline & & Valsartan+Kaptopril+Furosemid & 1 & & \\
\hline & & Captopril+Losartan+Amlodipin & 1 & & \\
\hline & & Ramipril+Furosemid+Spironolakton & 1 & & \\
\hline
\end{tabular}

Interaksi dengan taraf signifikansi 1 merupakan interaksi obat yang memiliki tingkat keparahan mayor (berat atau berbahaya) dan terdokumentasi established (terdokumentasi dengan baik). Interaksi ini termasuk jenis interaksi obat yang seharusnya diprioritaskan untuk dicegah dan diatasi karena efek potensial membahayakan jiwa atau menyebabkan kerusakan permanen. Adapun yang termasuk dalam interaksi obat ini adalah seperti Tabel IV

\section{Kajian interaksi obat berdasarkan signifikansi 2}

Interaksi dengan taraf signifikansi 2 merupakan interaksi obat yang memiliki tingkat keparahan moderat (sedang) dengan onset tertunda (tidak 
Tabel IV. Kajian Interaksi Obat Berdasarkan Signifikansi 1

\begin{tabular}{|c|c|c|c|c|c|c|}
\hline $\begin{array}{c}\text { Kode } \\
\text { Pasien }\end{array}$ & $\begin{array}{c}\text { Interaksi } \\
\text { Obat }\end{array}$ & Onset & Severity & Efek Interaksi & $\begin{array}{c}\text { Mekanisme } \\
\text { Reaksi }\end{array}$ & $\begin{array}{c}\text { Jumlah } \\
\text { Kasus }\end{array}$ \\
\hline $2,42,56$ & $\begin{array}{l}\text { Furosemid+ } \\
\text { Digoksin }\end{array}$ & Delayed & Major & $\begin{array}{l}\text { Gangguan } \\
\text { elektrolit akibat } \\
\text { diuretik }\end{array}$ & $\begin{array}{l}\text { farmakodina } \\
\text { mik }\end{array}$ & 3 \\
\hline \multicolumn{5}{|c|}{ Total Kasus } & 3 \\
\hline
\end{tabular}

Tabel V. Kajian Interaksi Obat Berdasarkan Signifikansi 2

\begin{tabular}{|c|c|c|c|c|c|c|}
\hline $\begin{array}{c}\text { Kode } \\
\text { Pasien }\end{array}$ & $\begin{array}{c}\text { Interaksi } \\
\text { Obat }\end{array}$ & Onset & Severity & $\begin{array}{c}\text { Efek } \\
\text { Interaksi }\end{array}$ & $\begin{array}{c}\text { Mekanisme } \\
\text { Reaksi }\end{array}$ & $\begin{array}{c}\text { Jumlah } \\
\text { Kasus }\end{array}$ \\
\hline $59,60,62$ & $\begin{array}{l}\text { Nifedipin+ } \\
\text { Ranitidin }\end{array}$ & Delayed & Moderat & $\begin{array}{l}\text { Terjadi } \\
\text { peningkatan } \\
\text { efek dari } \\
\text { nifedipin }\end{array}$ & Farmakokinetik & 3 \\
\hline \multicolumn{5}{|c|}{ Total Kasus } & 3 \\
\hline
\end{tabular}

langsung terjadi), dan mempunyai level kejadian interaksi obat suspected (interaksi obat diduga terjadi) (Tatro, 2001). Interaksi ini termasuk jenis interaksi obat yang seharusnya diprioritaskan untuk dicegah dan diatasi karena mempunyai bukti yang cukup rasional untuk kemungkinan terjadinya interaksi obat.

\section{Kajian interaksi obat berdasarkan signifikansi 3}

Interaksi dengan taraf signifikansi 3 merupakan interaksi obat yang memiliki tingkat keparahan minor (tidak berbahaya), dengan onset tertunda (tidak langsung terjadi), dan mempunyai level kejadian interaksi obat suspected (interaksi obat diduga terjadi). Akibat dari interaksi ini mungkin mengganggu atau tidak disadari, tetapi tidak mempengaruhi secara signifikan terhadap efek obat yang diinginkan.

\section{Kajian interaksi obat berdasarkan signifikansi 4}

Interaksi dengan taraf signifikansi 4 merupakan interaksi obat yang memiliki tingkat keparahan major/moderat (berbahaya) dan terdokumentasi possible dengan data kejadian yang sangat terbatas.

\section{Kajian interaksi obat berdasarkan signifikansi 5}

Interaksi dengan taraf signifikansi 5 merupakan interaksi obat yang memiliki tingkat keparahan minor (tidak berbahaya atau ringan) dan terdokumentasi unlikely dengan 
Tabel VI. Kajian Interaksi Obat Berdasarkan Signifikansi 3

\begin{tabular}{|l|l|l|l|l|c|c|}
\hline \multicolumn{1}{|c|}{$\begin{array}{c}\text { Kode } \\
\text { Pasien }\end{array}$} & \multicolumn{1}{|l|}{$\begin{array}{c}\text { Interaksi } \\
\text { Obat }\end{array}$} & Onset & Severity & Efek Interaksi & $\begin{array}{c}\text { Mekanisme } \\
\text { Interaksi }\end{array}$ & $\begin{array}{c}\text { Jumlah } \\
\text { Kasus }\end{array}$ \\
\hline $\begin{array}{l}2,4,7,8,13,16, \\
21,22,26,28, \\
33,36,43,46,53, \\
58,59,60,66,68, \\
70\end{array}$ & $\begin{array}{l}\text { Kaptopril+ } \\
\text { Furosemid }\end{array}$ & Delayed & Minor & $\begin{array}{l}\text { Meningkatkan efek } \\
\text { hipotensi, Farmakodinamik } \\
\text { mengurangi efek dari } \\
\text { loop diuretik, } \\
\text { meningkatkan risiko } \\
\text { hiperkalemia berat }\end{array}$ & 21 \\
\hline $1,37,43,44$ & $\begin{array}{l}\text { Ramipril+ } \\
\text { furosemid }\end{array}$ & Delayed & Minor & $\begin{array}{l}\text { Meningkatkan efek } \\
\text { hipotensi, Farmakodinamik } \\
\text { mengurangi efek dari } \\
\text { loop diuretik, } \\
\text { meningkatkan risiko } \\
\text { hiperkalemia berat }\end{array}$ & \\
\hline
\end{tabular}

Tabel VII. Kajian Interaksi Obat Berdasarkan Signifikansi 4

\begin{tabular}{|c|l|c|c|c|c|c|}
\hline $\begin{array}{c}\text { Kode } \\
\text { Pasien }\end{array}$ & \multicolumn{1}{|c|}{$\begin{array}{c}\text { Interaksi } \\
\text { Obat }\end{array}$} & Onset & Severity & Efek Interaksi & $\begin{array}{c}\text { Mekanism } \\
\text { e Interaksi }\end{array}$ & $\begin{array}{c}\text { Jumlah } \\
\text { Kasus }\end{array}$ \\
\hline 2,19 & $\begin{array}{l}\text { Kaptopril+ } \\
\text { Alopurinol }\end{array}$ & Delayed & Major & $\begin{array}{l}\text { Meningkatkan risiko } \\
\text { hipersensitifitas jika } \\
\text { Alopurinol diberikan } \\
\text { bersama Captopril }\end{array}$ & Unknown & 2 \\
\hline 27,61 & $\begin{array}{l}\text { Lisinopri+ } \\
\text { Alopurinol }\end{array}$ & Delayed & Major & $\begin{array}{l}\text { Meningkatkan risiko } \\
\text { hipersensitifitas jika } \\
\text { Alopurinol diberikan } \\
\text { bersama ACEI }\end{array}$ & Unknown & 2 \\
\hline 59 & $\begin{array}{l}\text { Kaptopril+ } \\
\text { Spironolakton }\end{array}$ & Delayed & Moderat & $\begin{array}{l}\text { dapat mengakibatkan } \\
\text { peningkatan Unknown } \\
\text { konsentrasi kalium } \\
\text { dalam serum Pasien } \\
\text { tertentu }\end{array}$ & 1 \\
\hline 2 & $\begin{array}{l}\text { Kaptopril+ } \\
\text { Digoksin }\end{array}$ & Delayed & Moderat & $\begin{array}{l}\text { Bisa meningkatkan } \\
\text { atau menurunkan } \\
\text { kadar plasma dari } \\
\text { Digoksin }\end{array}$ & Unknown & 1 \\
\hline
\end{tabular}

dokumentasi yang terbatas dan beberapa interaksi ini belum terbukti secara klinis.

Berdasarkan hasil kajian interaksi obat antihipertensi dengan obat lain pada pasien hemodialisis, maka kejadian interaksi obat terangkum sebagaimana Tabel IX dan Tabel X.
Setelah data penelitian mengenai interaksi obat secara teoritis berdasarkan taraf signifikansi, onset, dan severity menurut Tatro (2001) dievaluasi, diperoleh hasil bahwa interaksi obat antihipertensi yang paling banyak terjadi adalah pada taraf signifikansi 3 yaitu sebesar 27 kasus (45,76\%), Onset yaitu 
Tabel VIII. Kajian Interaksi Obat Berdasarkan Signifikansi 5

\begin{tabular}{|c|c|c|c|c|c|c|}
\hline $\begin{array}{c}\text { Kode } \\
\text { Pasien }\end{array}$ & $\begin{array}{c}\text { Interaksi } \\
\text { Obat }\end{array}$ & Onset & Severity & Efek Interaksi & $\begin{array}{c}\text { Mekanisme } \\
\text { Interaksi }\end{array}$ & $\begin{array}{c}\text { Jumlah } \\
\text { Kasus }\end{array}$ \\
\hline $\begin{array}{l}8,15,16,20 \\
26,30,42\end{array}$ & $\begin{array}{l}\text { Furosemid }+ \\
\text { Aminopilin }\end{array}$ & Rapid & Minor & \begin{tabular}{|l}
$\begin{array}{l}\text { Meningkatkan } \\
\text { inhibisi } \\
\text { furosemid }\end{array} \quad$ dari \\
\end{tabular} & unknown & 7 \\
\hline $\begin{array}{l}8,25,37,42 \\
47,55\end{array}$ & Furosemid+ PCT & Delayed & Minor & $\begin{array}{l}\text { Penurunan efektifitas } \\
\text { furosemid }\end{array}$ & Farmakodinamik & 6 \\
\hline 16 & $\begin{array}{l}\text { Propanolol+ } \\
\text { Furosemid }\end{array}$ & Rapid & Minor & $\begin{array}{l}\text { Aksi dari propanolol } \\
\text { meningkat }\end{array}$ & Farmakokinetik & 1 \\
\hline
\end{tabular}

Tabel IX. Rangkuman Kejadian Interaksi Obat Berdasarkan Taraf Signifikansi

\begin{tabular}{|c|c|c|c|}
\hline Taraf signifikansi & Jumlah kasus & Dari total kejadian & Persentase (\%) \\
\hline 1 & 3 & $(\mathrm{n}=59)$ & 5,08 \\
\hline 2 & 3 & $(\mathrm{n}=59)$ & 5,08 \\
\hline 3 & 27 & $(\mathrm{n}=59)$ & 45,76 \\
\hline 4 & 9 & $(\mathrm{n}=59)$ & 15,25 \\
\hline 5 & 17 & $(\mathrm{n}=59)$ & 28,81 \\
\hline Total & 59 & & $100 \%$ \\
\hline
\end{tabular}

Tabel X.Rangkuman Kejadian Interaksi Obat Berdasarkan Onset dan Severity

\begin{tabular}{|c|c|c|c|c|c|}
\hline \multirow{2}{*}{$\begin{array}{c}\text { Taraf } \\
\text { signifikansi }\end{array}$} & \multicolumn{3}{|c|}{ Onset } & \multicolumn{3}{c|}{ Severity } \\
\cline { 2 - 6 } & Rapid & Delayed & Major & Moderate & Minor \\
\hline 1 & - & 3 & 3 & - & - \\
\hline 2 & - & 3 & - & 3 & - \\
\hline 3 & - & 27 & - & - & 27 \\
\hline 4 & 3 & 6 & 4 & 5 & - \\
\hline 5 & 8 & 9 & - & - & 17 \\
\hline Jumlah kasus & $\mathbf{1 1}$ & $\mathbf{4 8}$ & 7 & $\mathbf{8}$ & $\mathbf{4 4}$ \\
\hline Total & $\mathbf{5 9}$ & $\mathbf{8 1 , 3 6}$ & $\mathbf{1 1 , 8 6}$ & $\mathbf{1 3 , 5 6}$ & $\mathbf{7 4 , 5 8}$ \\
\hline Persentase (\%) & $\mathbf{1 8 , 6 4}$ & $\mathbf{1 0 0 \%}$ & & $\mathbf{1 0 0 \%}$ \\
\hline Total & \multicolumn{5}{|c|}{} \\
\hline
\end{tabular}


delayed sebesar 48 kasus $(81,36 \%)$, dan severity yaitu minor sebesar 44 kasus $(74,58 \%)$ dari total 59 kejadian yang mengalami interaksi obat. Dari penelitian ini didapat interaksi farmakokinetika sebesar 7 kasus $(11,86 \%)$, interaksi farmakodinamik sebesar 37 kasus (62,71\%), dan unknown atau belum diketahui mekanisme interaksinya sebesar 15 kasus $(25,42 \%)$ dari total kasus sebesar 59 kejadian. Data mekanisme interaksi obat dapat dilihat pada Tabel XI. interaksi tersebut tidak bermakna secara klinis (Fradgley, 2003).

\section{Analisis Obat Yang Sering Berinteraksi}

Hasil penelitian menunjukkan jenis obat yang sering berinteraksi dengan obat lain pada pasien hemodialisis di bangsal rawat inap RSU PKU Muhammadiyah Yogyakarta adalah furosemid dan kaptopril. Data dapat dilihat pada Tabel XII.

Tabel XI. Data Mekanisme Interaksi Obat

\begin{tabular}{|l|c|c|}
\hline \multicolumn{1}{|c|}{ Mekanisme Interaksi } & Jumlah kasus & Persentase (\%) \\
\hline Farmakokinetik & 7 & 11,86 \\
\hline Farmakodinamik & 37 & 62,71 \\
\hline Un known / Belum diketahui & 15 & 25,42 \\
\hline TOTAL & 59 & $100 \%$ \\
\hline
\end{tabular}

Tabel XI menunjukkan bahwa interaksi obat terbanyak ada pada mekanisme farmakodinamik sebesar $62,71 \%$. Hal tersebut menunjukkan bahwa obat-obat yang diberikan saling berinteraksi pada sistem reseptor, tempat kerja atau sistem fisiologi yang sama sehingga terjadi efek yang aditif, sinergis (saling memperkuat), dan antagonis (saling meniadakan).

Beberapa alternatif penatalaksanaan interaksi obat adalah menghindari kombinasi obat dengan memilih obat pengganti yang tidak berinteraksi, penyesuaian dosis obat, pemantauan pasien atau meneruskan pengobatan seperti sebelumnya jika kombinasi obat yang berinteraksi tersebut merupakan pengobatan yang optimal atau bila
Tabel XII menunjukkan bahwa obat yang paling sering berinteraksi dengan obat lain yaitu furosemid dan kaptopril. Hal tersebut dikarenakan furosemid merupakan diuretik yang menjadi terapi utama untuk pasien gagal ginjal dan merupakan obat yang memerlukan kontrol dosis yang tepat sehingga dengan penggunaan dosis yang tidak tepat dapat mempengaruhi kerja obat. Sedangkan kaptopril adalah obat antihipertensi first line untuk gagal ginjal karena kaptopril terdialisis oleh proses hemodialisis sehingga monitoring perlu pada penggunaan kaptopril pertama kali pada dosis inisial. Pengetahuan jenis obat yang sering berinteraksi dapat mempermudah dalam mengidentifikasi 
Tabel XII. Data Distribusi Interaksi Obat Berdasarkan Signifikansi 1, 2, 3, 4 dan 5

\begin{tabular}{|c|l|c|}
\hline Signifikansi & Intreraksi Obat Dan Obat & Jumlah \\
\hline 1 & Furosemid+Digoksin & 3 \\
\hline 2 & Nifedipin+Ranitidin & 21 \\
\hline \multirow{2}{*}{3} & Kaptopril+Furosemid & 4 \\
\cline { 2 - 3 } & Ramipril+Furosemid & 2 \\
\cline { 2 - 3 } & Lisinopril+Furosemid & 2 \\
\hline \multirow{2}{*}{4} & Kaptopril+Alopurinol & 2 \\
\cline { 2 - 3 } & Lisinopril+Alopurinol & 1 \\
\cline { 2 - 3 } & Kaptopril+Spironolakton & 1 \\
\cline { 2 - 3 } & Kaptopril+Digoksin & 3 \\
\cline { 2 - 3 } & Kaptopril+Asetosal & 7 \\
\hline \multirow{2}{*}{5} & Furosemid+Aminopilin & 6 \\
\cline { 2 - 3 } & Furosemid+PCT & 1 \\
\cline { 2 - 3 } & Propanolol+Furosemid & 1 \\
\cline { 2 - 3 } & Propanolol+Vitamin C & 2 \\
\cline { 2 - 3 } & Amlodipin+Lansoprazol & 3 \\
\hline
\end{tabular}

adanya interaksi obat pada pengobatan pasien.

\section{Keterbatasan penelitian}

1. Penelitian ini retrospektif sehingga tidak dapat monitoring pasien untuk mengetahui akibat interaksi obat.

2. Data pada rekam medik kurang lengkap sehingga tidak dapat diketahui kondisi yang terjadi pada pasien setelah minum obat.

\section{KESIMPULAN}

Berdasarkan hasil penelitian dapat disimpulkan sebagai berikut:
1. Pola pengobatan antihipertensi yang paling banyak digunakan pada pasien hemodialisis di RSU PKU Muhammadiyah Yogyakarta periode tahun 2010 adalah kombinasi 3 obat antihipertensi yaitu $A C E I, C C B$, dan diuretik.

2. Terdapat 54, $79 \%$ (40 pasien) hemodialisis di bangsal rawat inap RSU PKU Muhammadiyah Yogyakarta periode tahun 2010 berpotensi mengalami interaksi obat.

3. Kejadian interaksi obat antihipertensi yang paling banyak terjadi adalah pada tingkat signifikansi 3 terdapat 27 kasus $(45,76 \%)$, Onset yaitu 
delayed sebesar 48 kasus $(81,36 \%)$, dan severity yaitu minor sebesar 44 kasus (74,58\%). Mekanisme interaksi terbanyak yaitu farmakodinamik 37 kasus $(62,71 \%)$ dari total 59 kejadian yang mengalami interaksi obat.

4. Obat antihipertensi yang sering berinteraksi pada pasien hemodialisis di bangsal rawat inap RSU PKU Muhammadiyah pada periode tahun 2010 yaitu furosemid dan kaptopril.

\section{SARAN}

1. Perlunya monitoring penggunaan obat oleh dokter dan apoteker.

2. Perlu ditingkatkan komunikasi antara farmasis dan dokter dalam menentuka terapi untuk mencegah terjadinya interaksi.

3. Sebaiknya dalam penulisan data di rekam medik dilakukan selengkap mungkin.

4. Hendaknya dilakukan penelitian dengan metode prospektif sehingga dapat diketahui efek yang ditimbulkan akibat interaksi obat.

\section{DAFTAR PUSTAKA}

Agarwal. R, 2006, Management of Hypertension in Hemodialysis Patients, Hemodialysis International, 10:241-248.

Anonim, 2000, Informatorium Obat Nasional Indonesia, diterjemahkan oleh Darmansjah, I., dan tim editorial, Departemen Kesehatan Republik Indonesia dan Dirjen POM, Jakarta.

Anonim, 2008, The Seventh Report Of The Joint National Committee on
Hypertension Evaluation and Treatment, Intermountain Healt Care, Patien and Provider Publications 801.442.2963.

Chazot C and Guillaume J, 2010, Intradialytic Hypertension: It Is Time to Act, Nephron Clinical Practice, 115: C182-C188.

Fredgley, S. J., 2003, Interaksi Obat, In Farmasi Klinis (Clinical

Pharmacy) Menuju Pengobatan Rasional dan Penghargaaan Pilihan Pasien (Aslam, M., Tan, C. K., dan Prayitno, A., Eds.), PT Alex Media Coumputindo, Jakarta. Hal: 119-134.

Grabe D.W., Low C.L., Bailie G.R., Eisele G., 1997, Evaluation of Drug Related Problems in an Outpatient Hemodialysis Unit and Impact of a clinical pharmacist, Clin Nephrol 47(2): 117-121.

Inrig JK, 2010, Intradialytic Hypertension: A Less-Recognized Cardiovascular Complication of Hemodialysis, Am J Kidney, 55(3):580-9.

National Kidney Foundation: K/DOQI, 2005, Clinical Practice Guideline for Cardiovaskular Disease in Dialysis Patients, Am J Kidney. Dis: $45 \% 51-$ SI53.

National Kidney and Urologic Diseases Information Clearinghouse (NKUDIC), 2009, Treatment Methods for Kidney Failure: Hemodialysis, the National Institute of Diabetes and Digestive and Kidney Diseases (NIDDK), USA. 
Rahardjo P., Susalit E., Suhardjono, 2001, Dialisis Buku Ajar Ilmu Penyakit Dalam, Jilid II, Edisi 3, Balai Penerbit FKUI, Jakarta, hal. 435-438.

Tatro, D.S., 2001, Drug Interaction Fact, $5^{\text {th }}$ Edition, Fact and Comparisons, Missouri California.

Walker R dan Edward C., 1999, Clinical Pharmacy and Therapeutics, Second Edition, Prodused by Adition Wisley Longma China United, Hongkong. Hal 247-248.

Weidman P, Maxwell M.H., Lupu A.N., 1971, Plasma Renin Activity and Blood Pressure in Terminal Renal Failure, New England Journal of Medicine. 285:757-762. 